\title{
AYURVEDIC MANAGEMENT OF SHWITRA (VITILIGO) - A CASE REPORT
}

\section{AURANGABADKAR K ${ }^{1}$, KHANDARE $S^{2 *}$ AND CHATUPHALE $\mathbf{G}^{3}$}

1: PhD Scholar, Parul Institute of Ayurveda, Parul University, Vadodara, Gujarat. Assistant Professor, Dept. Of Roga Nidan Evum Vikriti Vigyan, Govt. Ayurved College, Vadodara, Gujarat

2: Professor, Dept. Of Roga Nidan Evum Vikriti Vigyan, Parul Institute Of Ayurveda, Parul University, Vadodara, Gujarat

3: PhD Scholar, MGAC, DMIMS, Dept. Of Agad Tantra Evum Vidhi Vaidayk, Salod, Wardha, Maharashtra. Assistant Professor, Dept. Of Agad Tantra Evum Vidhi Vaidayk, Govt. Ayurved College, Vadodara, Gujarat

*Corresponding Author: Khandare S; E Mail: sunil.khandare260000@paruluniversity.ac.in

Received 12 ${ }^{\text {th }}$ Dec. 2021; Revised 14 ${ }^{\text {th }}$ Jan. 2022; Accepted $7^{\text {th }}$ Feb. 2022; Available online $5^{\text {th }}$ March 2022

\section{https://doi.org/10.31032/IJBPAS/2022/11.3.1074}

\begin{abstract}
Vitiligo is a common autoimmune skin disorder that causes pigmentation over body. It is of great sociomedical importance. Due to melanocytes deficiency, white spots appeared on body. Vitiligo have major impact on quality of life of patients, many of Vitiligo patients feel stigmatized and depressed by their condition. It can be correlated with Shvitra in Ayurveda. Due to side effects and limitation of the modern contemporary practice, some harmless and effective medicines are expected from Alternative medical sciences. Ayurveda has great potential to treat such autoimmune skin diseases. In Ayurveda treatment of shwitra kushtha includes shodhana

i.e. panchkarma and shaman chikitsa.

Here a case of 24 yr. old female patient of shwitra (vitiligo) treated with Ayurvedic management is recorded. This treatment includes aarogya vardhini vati, krumi kuthar rasa, manjistha kwath, swayambhuva guggul \& bakuchi taila.
\end{abstract}

Keywords: vitiligo, Autoimmune, Shvitra, kushta, Shodhana, shaman, Ayurveda, aarogya vardhini vati, krumi kuthar rasa, Maha Manjishthadikwath, swayambhuva guggul \& bakuchi taila 


\section{INTRODUCTION}

Vitiligo is a chronic disfiguring disease involved with systemic autoimmune process. It is characterized by constrained, idiopathic, progressive, hypo- pigmented or white patches of skin $^{1}$.

Vitiligo is also called hypo melanosis condition of the skin. This results in the hypo function or destruction of melanocyte. Melanocyte cell of the skin contains the Melanin which is very important for pigmentation of the skin. Melanin synthesis into the melanocyte cell is essential for normal color of the skin. According to modern medicine the cause of the Vitiligo is unknown till date. It may onset during any age but usually in second decade of life. It is Multifactorial disease, hence Genetic susceptibility is important factor in this case. Risk factors include positive family history, inflammatory diseases or autoimmune diseases. Prevalence of Vitiligo is $1 \%$ all over the world, while its incidence ranges from 0.1 to $>8.8 \%^{2}$.

Confirmation of diagnosis is possible by tissue or skin biopsy. Treatment for Vitiligo in conventional medicine includes topical steroids, systemic steroids, systemic PUVA, topical PUVA, surgically grafting also done in some conditions. PUVA therapy has side effects like hyperpigmentation, squamous cell carcinoma in white skin individuals, photo toxicity, solar elastosis, and cataract. UVB phototherapy is a safer and better alternative to PUVA therapybut is relatively expensive.

It can be co-related with Shvitra in Ayurveda due to the identical signs and symptoms which are; non exudative white, red or coppery-red colored patches, roughness, dryness, itching, burning sensation of the patches, loss and discoloration of the hair. In Ayurveda skin is one of the panchdyanendriya. Any skin disease causes physical, psychological and economical handicapping of the patient, as it is visible.

According to aacharya charak vachansi atathyani (Untruthfulness), krutaghna bhava (ungratitude), suranam ninda (Abusing god), guru gharshanam (Insulting teachers), paapa kriya (sinful deeds), purvakruta karma (Sinful deeds of previous birth) and virodhi annam (Consumption of mutually contradictory food) are causative factors of shvitra out of which virodhi annam (Consumption of mutually contradictory food) is important one ${ }^{3}$.

Now-a-days we see increasing number of skin diseases due to changing dietary habits, stressful lifestyle, addiction and sleeping pattern.

Considering the limitations of contemporary medicine system, Traditional medicines may be alternative of these unsatisfactory and harmful approaches and may provide some safe, easier, 
less complicating, cost effective and fruitful natural remedies for the disease. Ayurveda comprise so many potent formulations for the treatment of such autoimmune disease with chronic nature ${ }^{4}$.

Here a case of female patient suffering from (shwitra) Vitligo was treated with Ayurvedic therapy and Diet restriction.

\section{Case Report Demographic Data}

Patient name - ABCAge- 24 years

Sex - Female Occupation- Student

\section{Chief complaints (with duration)-}

- Hypo pigmented (white) patch on left calf posterior region since last one year

- Dimension of the patch: $4 \times 3 \mathrm{~cm}$

- The patch was itchy (Occasional, Mild)

- The spot was asymmetric, well defined whitish and without scaling.

\section{Past History:}

Personal history: There was no personal history of autoimmune disorders (like Atopic dermatitis, psoriasis, Asthma, etc). There was no personal history of trauma or surgery, any major psychological disorder, endocrinal disorder (Diabetes), or any history of treatment from psychiatrist.

\section{Medicinal history:}

She had allopathic medication history for last six months including corticosteroid, and multivitamins internal and external applications. She had found some improvement in starting phase of the treatment, but then there was no progress in that condition for last three months. Hence, she had come for Ayurvedic medication.

Family History: no any known family history found

\section{Personal History:}

Diet / Aahar: Akal Bhojan, Vishamashan, Virudha aahar, Ushna, ruksha, atisnigdha padhartha sevan, excessive sweet, sour and food which was heavy to digest

Vihara: ratri jagran, diwaswapna intermittentlyAddiction: tea (2-3 times/day)

\section{On examination:}

Pulse: $76 / \mathrm{min}$

BP: $110 / 70 \mathrm{~mm}$ of Hg Systemic

examination:RS: AEBE, B/L Clear

CVS: $\mathrm{S}_{1} \mathrm{~S}_{2}$ Normal, No MurmurCNS:

Conscious, Oriented Local examination:

Color: White

Appearance: Hypo Pigmented, Whitish Patch

Discharge: Nil

\section{Aturabala Pariksha}

> Prakriti: VK

$>$ Sara: Madhyam

> Samhanan: Madhyam

> Pramana: Madhyam

> Satmya: Madhyam 
> Satva: Madhyam

Aaharshakti:

- Abhyavaharana Shakti: Manda

- Jarana Shakti: Madhyam

> Vyayam Shakti: Madhyam

> Vaya: Yuva

\section{Samprapti ghatak}

Dosha:

- Pitta: Bhrajaka

- Vata: Udana \& Vyana

- Kapha: Sheleshaka

\section{Dushya:}

- Dhatu: Rasa, Rakta, Mamsa, Meda \& Lasika

- Mala: Loma

Agni: Jataragni \& Dhatwagni

> Agni Dushti Type: Agni Mandhya

> Srotasa: Raktavaha, Rasavaha

Srotodushti Type: Sanga

> Marga: Bahya Roga Marga

Udabhavasthana: Amashaya

Sancharsthana: Sarva Sareera

Through Tiryak Sira

> Vyaktisthana: Twacha

Swabhava: Chirakari

> Sadhyasadhyata: Krichhasadhya

Diagnosis: Shvitra (Vitiligo) (kaphaj)

\section{Treatment}

1. Arogyavardhini rasa [9] (250 mg) was prescribed with warm water before meal twice a day.
2. Krumi kuthar rasa $(250 \mathrm{mg})$ was prescribed with warm water before meal twice a day.

3. Maha Manjishthadi Kwatha (20ml) was prescribed twice a day with water.

4. Swayambhuva guggula

5. Bakuchi taila was prescribed for local application in morning followedby sun exposure for 30 minutes.

On $10^{\text {th }}$ day of local application Patient had complaint of slight itching and burning after application of bakuchi taila. Slight redness and itching was observed over applied area.

After two months, skinny spots were found appeared between the white patch and spot was become slight pink. No recurrent patches were observed in this period and pink color was persisting in the spots and patches. After seven months, patch decreased to almost half of the initial stage. 
Table 1: Prescribed Medicines and their Pharmacological actions andtherapeutic indications

\begin{tabular}{|c|c|c|c|c|}
\hline S. No. & Medicine & Dose with Anupana & $\begin{array}{c}\text { Pharmacol ogical } \\
\text { actions }\end{array}$ & Therapeuticindications \\
\hline 1 & Aarogya vardhini rasa & $\begin{array}{c}250 \text { mg twice a day before meal } \\
\text { with lukewarm water }\end{array}$ & $\begin{array}{c}\text { Antioxidant, } \\
\text { Antihyperli } \\
\text { pidemic, } \\
\text { hepatoprotective }\end{array}$ & $\begin{array}{l}\text { Kushtha (skin } \\
\text { disorders), Yakrutvikara } \\
\text { (Disorder of liver),Jirna Jwara } \\
\text { (Chronic fever),Meda dhatu dosh } \\
\text { a(Disorder of adipose tissue), }\end{array}$ \\
\hline 2 & Krumi KutharRasa & $\begin{array}{c}250 \text { mg twice a daybeforemeal } \\
\text { with lukewarm water }\end{array}$ & Krumi Nashak & $\begin{array}{lr}\text { Krumi } & \text { (intestinalworm } \\
& \text { infestation) }\end{array}$ \\
\hline 3 & $\begin{array}{l}\text { Maha Manjishthadi } \\
\text { Kwatha }\end{array}$ & $\begin{array}{c}20 \mathrm{ml} \text { twice a day (early morning } \\
\text { empty stomach, atnight before } \\
\text { meal) with water }\end{array}$ & $\begin{array}{l}\text { Rakta shodhaka } \\
\text { (Blood purifier) }\end{array}$ & $\begin{array}{c}\text { Vartarakta (Gout), Kushtha (Skin } \\
\text { disorders) }\end{array}$ \\
\hline 4 & Swayambhuva Guggula & $\begin{array}{l}500 \text { mg twice a day before meal } \\
\text { with lukewarm water }\end{array}$ & $\begin{array}{c}\text { Rakta shodhaka } \\
\text { (Blood purifier), } \\
\text { pittashamak } \\
\text { (pacify pitta dosha) }\end{array}$ & $\begin{array}{l}\text { Shvitra (vitiligo) \&other chronic } \\
\text { skin disorders }\end{array}$ \\
\hline 5 & Bakuchi Taila & $\begin{array}{c}\text { For local applicationin morning } \\
\text { followed by sun exposure for } \\
\mathbf{3 0} \text { minutes }\end{array}$ & & \\
\hline
\end{tabular}

\section{DRUG ACTION}

Shvitra is a kapha pradhana tridoshaja Vyadhi. Progression of this disease is rapid, so the management should be taken in proper time to arrest the pathogenesis.

1. Aarogya Vardhini Rasa ${ }^{5}$ Arogya vardhini rasa possess the pharmacological action like Kusthanasaka ${ }^{8}$ (can alleviate all types of skin disorder), Tridosha jvara nashaka (fever arising due to involvement of three humours). It is also used in yakrit vikara (liver disorders) ${ }^{6}$. Also the drug having the properties like- pachani (digestive), dipani $^{9}$ (appetizer), pathya (wholesome for channel), hridya (cardio protective), medonasaka (can alleviate the diseases arising from hyperlipidemia), malashuddhikari (cleaning of waste materials from body), increase kshudha (appetizer), Sarva roga prashamani ${ }^{7}$ (can alleviate all types of disorders from body).

2. Krumi Kuthar Rasa ${ }^{10}$ : it is used in the ayurvedic treatment of helminthiasis (intestinal worm infestation) \& anorexia. It balances vata \& kapha dosha. As krumi plays important role in the samprapti of shivtra, this drug is selected ${ }^{15}$.

3. Maha Manjishthadi Kwatha ${ }^{11}$ : it acts as a Raktaprasadan Draya (blood purifier). It detoxifies blood and aids to eliminate toxins accumulated in the body. It increases skin glow.

4. Swayambhuva Guggula ${ }^{12}$ : it is used in 
various skin disorders including shvitra. Ingredients like Bakuchi, Karanja, Guduchi, Nimba, Haridra reduce vitiated rakta dosha, the main cause of Kushtha (skin disorders). Shilatu, Suvarnamakshika, Mundatika, Kutaja \& Nagarmotha are effective pittashamak and also help reduce vitiated rakta dosha. Gomootra vishesh shodhit guggul enhances the efficiency. The main components of psoralea corylifolia (bakuchi) are psoralen, isopsoralen, bakuchiol, psoralidin, bakuchalcone, bavachinin, flavones, volatile oils, lipids used for the treatment of vitiligo by virtue of their melanogenic action.

5. Bakuchi Taila: For local application Bakuchi taila is used. Bakuchi (Psoralea corylifolia Linn.) is a renowned herb with many therapeutic properties ${ }^{13}$. In Ayurvedic system of medicine, Bakuchi seeds are used for the treatment of Vitiligo. It contains psoralens, which on exposure to the sun bring out melanin in the depigmented lesions ${ }^{14}$. Psoralen is an active component which is used topically as well as systemically in the treatment of vitiligo.

\section{CONCLUSION}

From the above discussion, we have concluded that Ayurvedic management i.e. aarogya vardhini vati, krumi kuthar rasa, Mahamanjishthadi kwath, swayambhuva guggul \& bakuchi taila is successful in the management of Shvitra.

As far As the disease chronicity is concerned, for more effective results the treatment duration should be lengthened.

This treatment protocol should be clinically evaluated on large number of patients to confirm their efficacy.

\section{REFERENCES}

[1] Vitiligo. Problems and Solutions Lotti T. \& Hercogova J. , Editors, Marcel Dekker, Inc., New York (NY), 2004

[2] Srivastava G. Vitiligo- Introduction Asian Clinic. Dermatol 1994; 1:1-5.

[3] Sharma, R. K. And Dash, B., English Translation On Caraka Samhita Of Agnivesha, Chikitsa Sthana; Chapter 7, Verse: 177, Edtn., Chowkhambha Sanskrit Series, Varanasi, 2014

[4] Shingadiya RK, Sharma R, Bedarkar P, Prajapati PK. Autoimmune bullous skin disease managed with ayurvedic treatment: A case report. Ancient Sci Life 2017; 36:229-33.

[5] Ambikadatta shastri. Rasaratna Samuchchya. 9th edition. Chapter no-20. Verse no-

87. Varanasi: Chaukhamba Sanskrit Publisher;1994. p. 400 
[6] Kaviraj Govinda Das Sen.

Bhaisajyaratnavali. Siddhipada Hindi Commentary, Prof. Siddhinandana Mishra editor. 1st edition. Kustharogadhikara, Chapter no-54, Verse no-117, Varanasi: Chaukhamba Surbharati Prakashana; 2012.p.871

[7] Ambikadatta shastri. Rasaratna Samuchchya. 9th edition. Chapter no-20. Verse no 87. Varanasi: Chaukhamba Sanskrit

Publisher;1994. p. 400.

[8] Kumar G, Srivastava A, Sharma SK, Gupta YK. Safety evaluation of an Ayurvedic medicine, Arogyavardhini vati on brain, liver and kidney in rats. J Ethnopharmacol. 2012;140:151-60.

[9] Anonyms. Rasatantrasara and Siddhayoga Sangraha. 1st edition. Ajmer, Rajasthan: Krishna Gopal Ayurveda Bhavana Publisher; 2015 .p.150-153)

[10]Rasa Tantra Sara-Siddha Yoga Sangraha-Kharaliya Raayana, 60

[11] Sharangadhara Samhita, Madhyam Khand, 2/140-145

[12] Bha. Pra. Madhyam. Kustha Roga 69-72

[13] Bhava Prakasha of Sri Bhavamishra by Brahmasankara Mishra and Rupalalji Vaisya. Part 1, 11th ed.
Varanasi, Chowkamba Sanskrit Series; Bakuchi, Haritakyadi Varga. 2002, p.123-4.

[14] Ajay Dhanik, Sujatha N, Rai NP. Clinical evaluation of the efficacy of Shvitrahara kashaya and lepa in vitiligo, AYU 2011; 32(1):66-9.

[15] Yadavji Trikamji Acharya, Sushruta Samhita With Nibandhasangraha Commentary Of Sri Dalhanacharya, Reprint Edtn.,Chaukambha Sanskrit Samsthan, Varanasi, 2010, Nidan Sthana 5 / 6 . 